\title{
Evaluation of Nutrients Analysis and Organoleptic Characteristics of Pumpkin Seed Flour Incorporated Flavoured Drink
}

\author{
Geethanjali Santhanam ${ }^{1}$, Saratha Sathappan ${ }^{2}$ \\ ${ }^{1,2}$ Department of Home Science, Mother Teresa Women "e University, Kodaikanal, Tamilnadu, India
}

\begin{abstract}
The pumpkin (Cucurbita moschata) is an annual dicotyledonous vegetable, belonging to the Cucurbitaceous family. The top pumpkin producing countries include Illinois, India, Ohio, Pennsylvania, and California. Pumpkin is one of the most popular crops in the United states, about 1.5 billion pounds (680,000,000 kilograms) produced each year. Pumpkin (cucurbits moschata) has received considerable attention in recent years because of the nutritional and health protective values of the seeds. The seed is an excellent source of protein and also has pharmacological activities such as anti-diabetic, anti-fungal, anti-bacterial, anti-inflammation activities and antioxidant effects. This is the context where appearance the concept of "Functional foods" they are good source of calories, proteins, Carotenoids, minerals, fibre and phytosterols which contribute in contribute in regulating cholesterol. They also have omega 3 and omega 6 fatty acids needs for hormone balance, brain function and skin health. Pumpkin seed (Cucurbita moschata) considered a poor man's vegetable, contains dietary antioxidants, and phyto nutrients which provide bioactive mechanism to reduce free radical induced oxidative stress and probably play a role in the prevention of aging various diseases associate with oxidative stress such as cancer, cardiovascular and neurodegenerative diseases. It have a better mineral profile than many other minerals. Hence the present study aimed to develop health drink and to evaluate its nutritional, sensory characters. The present sarticle entitled "evaluation of nutrients analysis and organoleptic characteristics of Pumpkin Seed Flour incorporated flavored drink".
\end{abstract}

Keywords: Pumpkin seeds, Nutrient rich, Pumpkin Seed Flour incorporated flavored drink, Fortification.

\section{Introduction}

Pumpkin seeds, also known as pepitas, are small, flat, green, edible seeds. Most pumpkin seeds are covered by a white husk, although some pumpkin varieties produce seeds without them. Pumpkin seeds are a popular snack that can be found hulled or semi - hulled at most grocery stores. Pumpkines most valuable elements are included in its part which is most commonly disregarded as waste, namely pumpkin seeds. Pumpkin seeds are rich in medicinal and nutritive components, due to which reason they are applied in therapeutic purposes across the globe. Food is one of our most basic needs, which provides us energy for everything we do and also for all involuntary functions of our internal organs. Nuts are low in saturated fatty acids and high in monounsaturated and polyunsaturated fatty acids (Srilakshmi, 2008). Plants that have a close relationship to the soil are often special sources of mineral nutrients, and pumpkin (and their seeds) is no exception. Our food rating process found pumpkin seeds to be a very good source of the minerals phosphorus, magnesium, and manganese, and a good source of the minerals zinc, iron, and copper (Glew RH et al., 2006).

The nutritional profile of pumpkin seeds includes information on a full array of nutrients, including carbohydrates, sugar, soluble insoluble fiber, sodium, vitamins, minerals, fatty acids, amino acids and more.The study facilitates to utilize the low cost nutritious food. This present study increases the new varieties of nutritious food products in a market. Most of the commercial flavored drinks available in the market are high in cost and also less nutritious. There is a wide scope in different forms of nutritious flavored drink with low cost.
Tryptophan present in these seeds aids in milk production in lactating mothers and used to reduce postpartum swelling of the hands and feet. Hence Pumpkin seeds serve as a good nutritious snack and helps in promoting good health.

According to Eller (2007), as a nutritious snack, $1 / 4$ cup of pumpkin seeds contain under 200 calories. This amount also provides 15 to 50 percent of several important nutrients including protein, zinc, iron, magnesium and manganese. The seeds also contain beneficial fatty acids and amino acids. Pumpkin seeds have one of the highest levels of Antioxidants of any nut, seed or food. They are also loaded with tons of vitamins and minerals that the body needs. A handful a day to keep the doctor awayee (Leung, 1996). The present study was undertaken to evaluation of nutrients analysis and organoleptic characteristics of Pumpkin Seed Flour incorporated flavored drink".

\section{Materials and Methods}

\section{Selection of raw materials and Procedure}

Pumpkin seed were collected from the local market at Nilakkottai. The pumpkin seed were collected washed, sundried, and roasted and then it was manually decorticated. The decorticated seeds were powdered by electric mixer. The flour was packaged in an air -tight plastic container and kept in refrigerator until used.

Development of Pumpkin Seed Flour incorporated flavored drink

The preparation method and ingredients for pumpkin seed incorporated flavored drink as follow. 


\section{International Journal of Science and Research (IJSR) \\ ISSN (Online): 2319-7064 \\ Index Copernicus Value (2013): 6.14 | Impact Factor (2014): 5.611}

Pumpkin Seed Incorporated Flavored Drink

\begin{tabular}{|c|c|}
\hline Ingredients & Sample - I \\
\hline Pumpkin Seed flour & $30 \mathrm{~g}$ \\
\hline Whole Milk & $100 \mathrm{ml}$ \\
\hline Jaggery & $30 \mathrm{~g}$ \\
\hline Safflower & $2 \mathrm{~g}$ \\
\hline Cardamom & $1 \mathrm{~g}$ \\
\hline
\end{tabular}

Sample I- Pumpkin Seed Flour incorporated flavoured drink (cardamon flavoured)

\section{Whole milk}

Milk is available in a variety of forms that are differentiated by their fat content. Milk is a wholesome food which contains many nutrients like vitamins, minerals and protein.
It is essential to maintain good health of children, adolescents and adults. The flavoured drink was prepared with whole milk to make it more delicious.

\section{Method of preparation}

Pumpkin Seed Flour incorporated cardamom or vanilla flavoured drink

- Boiled whole milk and jaggery, Pumpkin Seed Flour, safflower, cardamon powder was added.

- Next step flavoured added one gram cardamom powder.

- The contents were blended thoroughly in a mixer.

- The Pumpkin Seed Flour health drink was served chill.

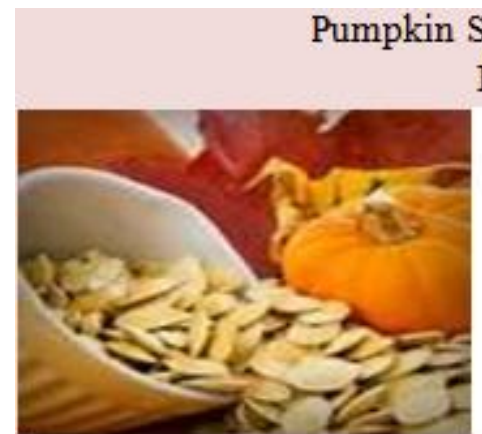

Raw Pumpkin Seed<smiles>CC=CC</smiles>

Roasted Pumpkin
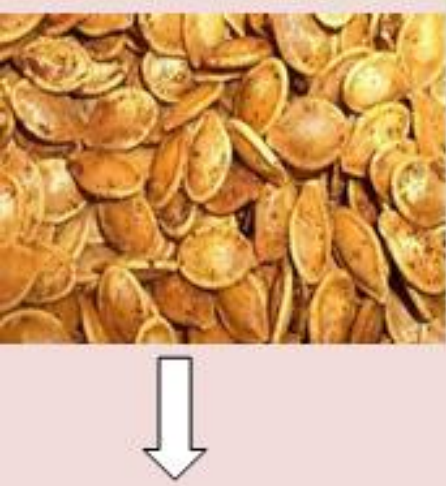

PS Flour

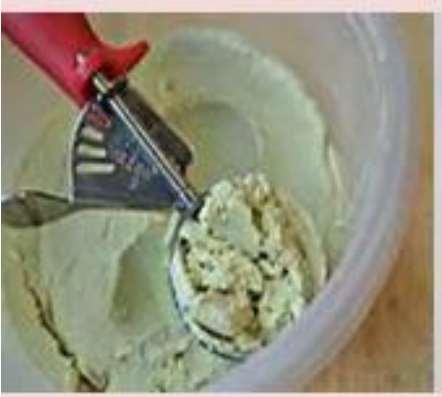

\section{Prepared Ingredients}
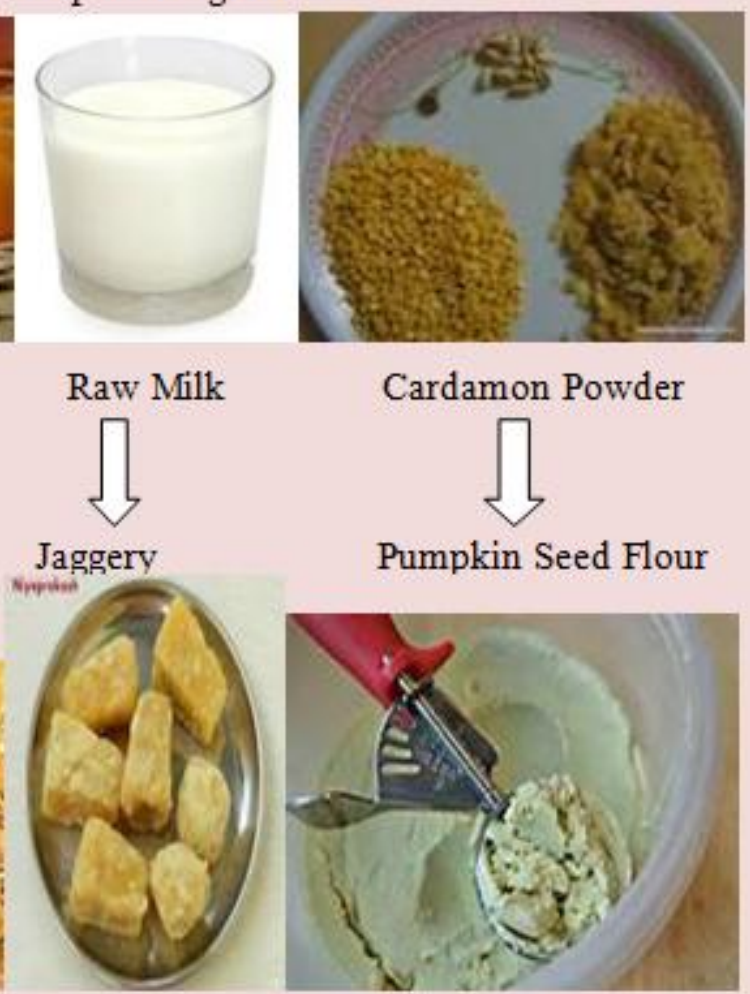

Pumpkin Seed Flour
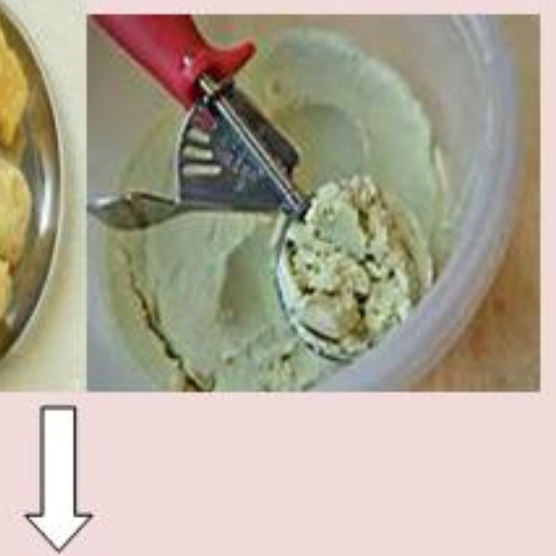

Saffron

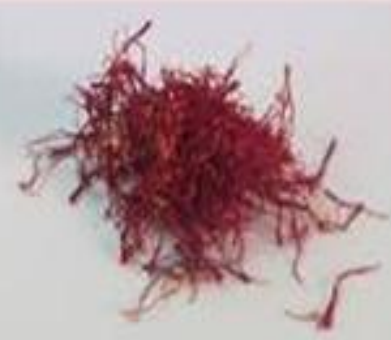

\section{Estimation of nutrient analysis}

The nutrient estimation analysis was conducted to estimate the nutrient content of the incorporated flavored drinks. The nutrients such as carbohydrate, protein, fat,moisture, tannin, phytic acid, were estimated. 


\section{International Journal of Science and Research (IJSR) \\ ISSN (Online): 2319-7064 \\ Index Copernicus Value (2013): 6.14 | Impact Factor (2014): 5.611}

The nutrient estimation was done by analysis which was carried out in Kodai Darwin Research Institute and Technology at Kodaikanal. The developed products were analyzed for their phyto chemicals tannin, phytic acid content. The phyto chemical estimation was done by analysis which was carried out in Chromo park research center Namakkal.

\section{Chemical Analysis}

\begin{tabular}{|c|c|c|c|}
\hline S.NO & Parameter & Method & Reference \\
\hline 1. & Moisture & Oven drying & AOAC (1995) \\
\hline 2. & Protein & $\begin{array}{l}\text { Lowry"s } \\
\text { method }\end{array}$ & Hart and Fisher (1971) \\
\hline 3. & Fat & $\begin{array}{c}\text { Felican } \\
\text { Equipment }\end{array}$ & Hart and Fisher (1971) \\
\hline 4. & $\begin{array}{c}\text { Total } \\
\text { Carbohydrate }\end{array}$ & $\begin{array}{l}\text { Anthrone } \\
\text { Method }\end{array}$ & $\begin{array}{c}\text { Sadasivam and } \\
\text { Manickam(1996) }\end{array}$ \\
\hline 5. & Phytic acid & Calorimeter & $\begin{array}{l}\text { Wheeler and Ferrel } \\
\text { (1971) }\end{array}$ \\
\hline 6. & Tannin & $\begin{array}{l}\text { vanillin-HCL } \\
\text { in methanol } \\
\text { method }\end{array}$ & Price (1978) \\
\hline
\end{tabular}

\section{Sensory Quality}

Pumpkin Seed Flour incorporated flavored drink were evaluate for their sensory attributes by a panel of 30 untrained members using Hedonic rating scale (Srilakshmi ,2010) and numerical score method. Sensory characteristics of developed Pumpkin Seed Flour incorporated flavored drink.

\section{Organoleptic evaluation of the flavored drink}

The Institute of Food Technologies (IFT) defines sensory evaluation as "The scientific disciple used to evoke measure, analyze and interpret human reactions to those characteristics of foods and beverages as they are perceived by the senses of sight, smell, taste, touch and healing (Murano, 2003). The term ,flavors ${ }^{e e}$ includes taste, smell and feeling on the tongue. The sense of taste is limited to three characteristics namely sweet, salty and bitter (Swaminathan, 2004). Organoleptic evaluation is done to estimate the acceptability of the prepared Pumpkin Seed Flour incorporated flavored drinks. The Numerical score card rating was used to sense the parameters like Appearance, Colour, Flavor, Mouth feel, Texture and Taste of the Pumpkin Seed Flour incorporated flavored drinks. Untrained (taste) panel members were selected for the evaluation and the panelists were asked to assess the degree of liking for each sample and the scores obtained were tabulated. Taste may be defined as the sensation derived from food as interpreted through the tongue to brain sensory system. The four primary taste sensations are sweet, salty, sour, bitter and fifth sensation is Unami (delicious) all triggers the brain's response (Murano, 2003).

The organoleptic evaluation was conducted to assess the acceptability developed products. The Pumpkin Seed Flour incorporated flavored drink were assessed by untrained panel members (B .Srilakshmi 2006). The 30 respondents were selected from Mother Teresa Women's University students for sensory evaluation .Hedonic rating scale and numerical rating scale was used for this analysis.

\section{Analysis data}

The data analyzed by various statistical analysis methods such as Mean,Standard deviation, ANOVA ( Analysis of variance)

\section{Results and Discussion}

The results of the analysis such as nutrient content, phyto nutrient content and sensory acceptance of the developed product was analyzed and discussed under this heading. The results shows

The nutrient content of the developed Pumpkin Seed Flour incorporated flavored drink

\begin{tabular}{|c|c|}
\hline Nutrients & Amounts in units \\
\hline Energy & $149.2 \mathrm{Kcal}$ \\
\hline Carbohydrate & $15 \mathrm{~g}$ \\
\hline Protein & $13.3 \mathrm{~g}$ \\
\hline Fat & $4 \mathrm{~g}$ \\
\hline Moisture & $7 \mathrm{~g}$ \\
\hline
\end{tabular}

The table result reveals that energy, carbohydrate and protein level is higher in Pumpkin Seed Flour incorporated flavored drink.

Phyto chemical present in Pumpkin Seed Flour incorporated flavoured drink

\begin{tabular}{|c|c|}
\hline Phyto chemicals & Amount \\
\hline Phytic acid $\mu \mathrm{g}$ & 3 \\
\hline Tannin $\mathrm{mg}$ & Negative \\
\hline
\end{tabular}

The developed products contain $3 \mu \mathrm{g}$ of phytic acid and tannin content analysis reveled the negative status.

Comparison of nutrient between incorporated Pumpkin Seed Flour flavoured drink and commercial orange flavoured drink

The Pumpkin Seed Flour incorporated flavoured drink excellent source of protein, fat, carbohydrate, and less than commercial orange flavoured drink. The commercial orange flavoured drinks contain various nutrients. The nutrient contents such as energy, carbohydrate, protein, Fat were presented below low in the Table.

Pumpkin Seed Flour flavoured drink and compared commercial orange flavoured drink amount per $100 \mathrm{ml}$

\begin{tabular}{|c|c|c|}
\hline Nutrients & Amounts in units & Amounts in units \\
\hline Energy Kcal & 149.2 & 32.4 \\
\hline Carbohydrate g & 15 & 8.1 \\
\hline Protein g & 13.3 & 0 \\
\hline Fat g & 4 & 0 \\
\hline Moisture g & 7 & 5 \\
\hline
\end{tabular}

The results found that (Pumpkin Seed Flour incorporated flavoured drink) contain excellent sources of $149.2 \mathrm{kcal}$, rich source of carbohydrate $15 \mathrm{~g}$ than other nutrients. 


\section{International Journal of Science and Research (IJSR) \\ ISSN (Online): 2319-7064}

Index Copernicus Value (2013): 6.14 | Impact Factor (2014): 5.611

Sensory evaluation of developed products (pumpkin seed flour incorporated flavoured drink and commercial orange flavoured drink ) By Hedonic scale method

\begin{tabular}{|l|c|c|}
\hline \multicolumn{1}{|c|}{ Variables } & $\begin{array}{c}\text { Sample I } \\
(\% \text { n=100 })\end{array}$ & $\begin{array}{c}\text { Sample II } \\
(\% \text { n=100 }\end{array}$ \\
\hline Appearance Marks & 60 & 43 \\
Excellent (5) & 33 & 20 \\
Very Good (4) & - & 20 \\
Good (3) & 7 & 10 \\
Fair (2) & - & 7 \\
Poor (1) & & \\
\hline Taste Marks & 77 & 36 \\
Excellent (5) & 13 & 27 \\
Very Good (4) & 7 & 17 \\
Good (3) & 3 & 13 \\
Fair (2) & - & 7 \\
Poor (1) & & \\
\hline Texture Marks & 30 & 33 \\
Excellent (5) & 57 & 27 \\
Very Good (4) & 10 & 20 \\
Good (3) & 3 & 13 \\
Fair (2) & - & 7 \\
Poor (1) & & \\
\hline Flavour Marks & 47 & 43 \\
Excellent (5) & 50 & 10 \\
Very Good (4) & - & 23 \\
Good (3) & 3 & 17 \\
Fair (2) & - & 7 \\
Poor (1) & 67 & 37 \\
\hline Mouth Feel Marks & 17 & 13 \\
Excellent (5) & 3 & 17 \\
Very Good (4) & - & 20 \\
Good (3) & - & 13 \\
Fair (2) & - & 27 \\
Poor (1) & - & 33 \\
\hline Over all acceptability Marks & & - \\
Excellent (5) & & \\
Very Good (4) & & \\
Good (3) & & \\
Fair (2) & & \\
Poor (1) & & \\
\hline & & \\
\hline
\end{tabular}

The table results explain that the 60 percent of the respondents provide high score for sample- I (pumpkin seed flour incorporated flavoured drink) and sample II (commercial orange flavoured drink products) and for its appearance. 77 percent of the respondents provide high score for sample- I (pumpkin seed flour incorporated flavoured drink) and sample II (commercial orange flavoured drink products) and for its taste. Excellent 30 percent of the respondents provide high score for sample II (commercial orange flavoured drink products) and sample- I (pumpkin seed flour incorporated flavoured drink) and for its 30percent texture.47 percent of the respondents given excellent flavor score for sample -I (Pumpkin Seed Flour incorporated flavoured drink). Excellent 67 percent of the respondents provide high score for sample- I (pumpkin seed flour incorporated flavoured drink) and for its sample II (commercial orange flavoured drink products) and 27 percent mouth feel. Excellent 67 percent of the respondents provide high score for sample- I (pumpkin seed flour incorporated flavoured drink) and for its sample II (commercial orange flavoured drink products) and 27 percent over all acceptability.
Finally the results concluded that the for sample -I (pumpkin seed flour incorporated flavoured drink) got an excellent appearance, taste, flavor, mouth feel, over all acceptability score by the respondents the sample II (commercial orange flavoured drink product. Sample II (commercial orange flavoured drink products) got an excellent texture score by the respondents the sample I (Pumpkin Seed Flour incorporated flavoured drink) had and good texture. The overall acceptability was highly acceptable for sample I (Pumpkin Seed Flour incorporated flavoured drink.

Comparison of Sensory evaluation scores of developed products (pumpkin seed flour incorporated flavoured drinks) by Numerical score card method

The sensory acceptance of the developed products was done by Numerical score card method. The sensory characters differ from every individual and the products. The differentiations between the developed products were statistically assessed by student " $F$ " test. The results of the analysis were presented in table.

Table: Comparison Sensory evaluation scores of developed products (pumpkin seed flour incorporated flavoured drinks) by Numerical score card method

\begin{tabular}{|c|c|c|}
\hline Variables & Sample I & Sample II \\
\hline & $\%(\mathrm{n}=100)$ & $\%(\mathrm{n}=100)$ \\
\hline Excellent (above 90) & 47 & 29 \\
\hline Very good (81-90) & 50 & 27 \\
\hline Good (71-80) & 3 & 33 \\
\hline Fair (61-70 & - & - \\
\hline Poor (below 60) & - & 13 \\
\hline
\end{tabular}

From the table results describes that 47 percent of the respondents provided excellent score (above 90) for sample I (pumpkin seed flour incorporated flavoured drink). Very good score (81-90) was provided by 50 percent of the respondents for sample I (pumpkin seed flour incorporated flavoured drink) and sample II (Commercial orange flavoured drink products) 27 percent. Good score (71-80) was provided by 3 percent of the respondents for sample I (pumpkin seed flour incorporated flavoured drink) and 33 percent sample II (Commercial orange flavoured drink products). Poor (below 60) was provided by 13 percent of the respondents for sample II (Commercial orange flavoured drink products).

These results concluded that sample -I (pumpkin seed flour incorporated flavoured drink) was highly acceptable by the respondents.

\section{Conclusion}

The results of the analysis concluded that the pumpkin seed flour incorporated flavored drink has contain the following nutrients such as energy, carbohydrate and protein is higher. The developed products contain $3 \mu \mathrm{g}$ of phytic acid and tannin content analysis revealed the negative status. Sample -I (pumpkin seed flour incorporated flavoured drink) got an excellent appearance, taste, flavor, mouth feel, over all acceptability score by the respondents the sample II (commercial orange flavoured drink product. Sample II (commercial orange flavoured drink products) got an 
excellent texture score by the respondents the sample I (Pumpkin Seed Flour incorporated flavoured drink) had and good texture. The overall acceptability was highly acceptable for sample I (Pumpkin Seed Flour incorporated flavoured drink.

\section{References}

[1] A.O.A.C. (2000): Association of Official Agricultural Chemists. Official Method of Analysis.17th Ed. Vol. 11.Washington U.S. A.

[2] Abd El-Aziz; A.B. and Abd El- Kalek, H.H. (2011): Antimicrobial proteins and oil seeds from pumpkin (Cucurbita moschata). Nature and Science, 9(3):105119.

[3] Akwaowo, E., B.A. Ndon and E.U. Etuk, 2000. Minerals and antinutrients in fluted pumpkin (Telifairia occidentalis Hook ). Food Chem., 70 235-240.

[4] Al-Zuhair H, Abdel-Fattah AA, Abd-el-Latif HA.Efficacy of simvastatin and pumpkin-seed oil in the management of dietary-induced hypercholesterolemia. Pharm Res 1997; 35:403e8.

[5] AOAC, 1990 Official Methods of Analysis $15^{\text {th }}$ Edn., Association of Official Analysis Chemists, Airlington, VA, United States.

[6] Applequist WL, Avula B, Schaneberg BT et el. Comparative fatty acid content of seeds of four Cucurbita species grown in a common (shared) garden. Journal of Food Composition and Analysis, Volume 19, Issues 6-7, September-November 2006, Pages 606-611.

[7] Bombardelli, E. and P. Morazzoni, 1997. Curcubita pepo L. Fitoterapia, 4: 68.

[8] Bradbury,J.H., J.G. Collins and N.A. Pyliotis ,1984 . Digestibility of protein of the histological components of cooked and raw rice . Br. Nutr., 52: 507-513.

[9] Buck AC (2004).Is there a scientific basis for the therapeutic effects of serenoarepens in prostatic hyperplasia. Mechanis of action. J Urol 172; 1792 1799.

[10] Caili F, Huan S, Quanhong L. A review on pharmacological activities and utilization technologies of pumpkin. Plant Foods Hum Nutr 2006;61:73e80. 